\section{p.28 歴史的研究}

55. 1830.40年代のドイツにおける学校体育と社丟体 育の対立とその克胑について

東京教育大学○成 田十公的

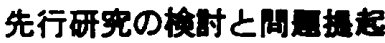

1872年，ドイッ体育教師这盟の会鿁て，「ドイッ学校 体育の創設者フドルフ・シュピース」とたたえられて以 来, 今日まで, シュピースに明する研究は，ほほ一致し て，ドイツ近代学校体育の磪立にはたした彼の役割を明 らかにすることに集中している.そして，シュピースの 思想と実践を貝くものが，一方では，反対制的社会体有 と体制的学校体育の対立, 他方では, ヤーンのッルネン の学校へのくり入れによる骨抜きと臣民の兵役訓散とし ての学校体育の確立という体育政策のもとで，変页した 国民教育への学校，社会体育の梳合的等入の方法如何と いう，時代的課題の解決であつたことを，これまでの研 究は充分明らかにしているとは言えない。

背最ししての学校・社会体育の対立

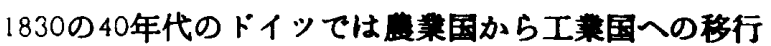

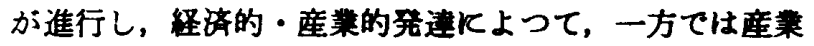
ブルショアジーの力が增大し，他方ては，民衆の生活の 困穿方泪立つてきた，そして，一方に「人間の棆利の解
放」と「祖国の紏一」をめざす人々と，他方にくづれか かつた絶対王制を椎持しようとする人々との対立が激化 していた.

ヤーンK発する社会体育は，これらの進歩的为力に支 えられて南部ドイッを中心に急速に発展し，反体制活功

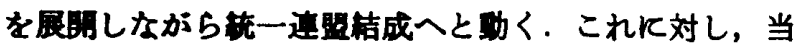
局はそれへの弾压を強化しながら，一方では，䎦対王制 の支拄である軍人清成の剖堜として学校体有の确立を求 めようとする．しかし，当時学校体育実践の理論は何す なかつた. シュピース体育が登场するのは，このような

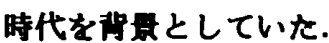

シュピース体市の二つの空味

シュピースはまずャーン体育克服のために，学校体育 の礁立を求めるが，同時に，この基磁教育としての学校 体育とその粈㨪数育としての社会体育とが統合されるこ とによつて，始めて体育は国民のものになるとし，その 実現に努力した。

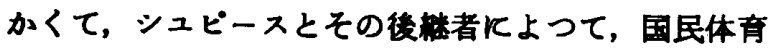
における学校・社会体育の幥造的発展がなされるが，同

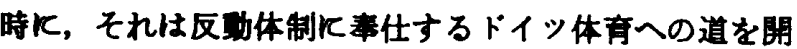
いた.
56. Carl Diem の思思体系（その6）

Asiatisehe Reiteropiele を中心にして(I) 大臤体育大学O加 元 和

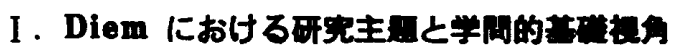

佊の polospiel K明する研究はつぎの 3 点Kその主昌 がおかれているといえる，1）polo の起原，2) polo の 史的展開，3）polo の史的意部などの 3 点てある. また こうした主题を页く基硯的视角は，1）文化的事象と polo との间係，2）歴史的 - 社会的事象と polo との网 係を明らかにすることである.

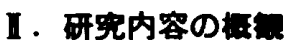

a) polospiel の起原 Diem K执れば，その起原は古

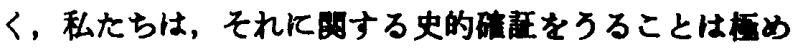

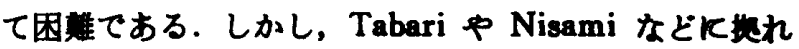
は，その起原はアケィネス胡まで邀ることが出来る。ま た，その原初的 spiel として, Diem は Kok-buri ゃ Dscheridspiel を举げているが, その Spiel としての形 式と内容から推詥すれば, polo の原初的 Spiel とみな すことには多少の危険が存するであろう.

b) polospiel の史的展用; 6 世紀以 15世仁に至万ま て，为多の歴史的・社会的武新を程て，イラン民族の文 化・宗教・政治と同漛， polo それ自体の展開すまたそ

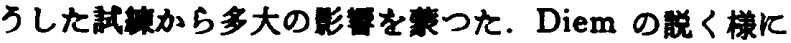
こうしたイラン民族と他民族との現实的的係を通して， polo は，乘ローマやそれを通しての西ヨーロッパのの

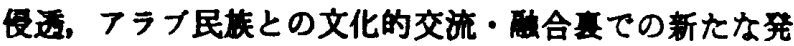
展，中央フジフへの搪敞と柬方フジアへの侵透・定着を 完了したのである.

c) polospiel の史的意散; Diem は，1）生の表出と

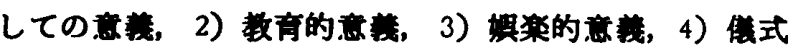
的意億，5）文芸的意湆，6）戦士のトレーニング的意義 などを举げているか，こうした Diem 流の意祴づけは， 史的事争の内容説明的であつて，本当の恶味の意普とは

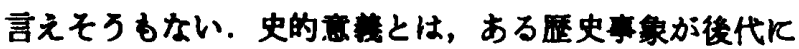
いかなる野力を持つたか視点をおいた方がよいであ ろう.

\section{I. 定的洁酳}

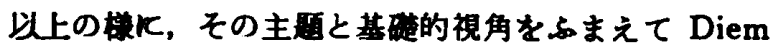

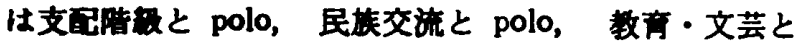
poloの间保次いて遍究してきたといえる，しかし彼に

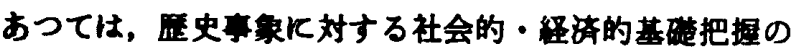

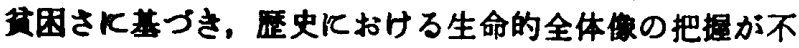
十分といえよう. 